\title{
TRABALHO DE MULHERES EXECUTIVAS NO BRASIL NO FINAL DO SÉCULO XX
}

\author{
CRISTINA BRUSCHINI \\ Departamento de Pesquisas Educacionais da Fundação Carlos Chagas \\ cbrusch@fcc.org.br \\ ANDREA BRANDÃO PUPPIN \\ Faculdade de Educação da Universidade Federal Fluminense - Rio de Janeiro \\ puppin@ccard.com.br
}

\section{RESUMO}

\begin{abstract}
Oartigo tece considerações sobre o trabalho das mulheres executivas no Brasil, no final do século XX. Na primeira parte, com base em estatísticas oficiais (Censos e Pesquisas Domiciliares, dados do Ministério do Trabalho, Ministério da Educação e outros), apresenta algumas tendências gerais da inserção laboral das brasileiras nesse período, visando compor o cenário no qual o trabalho das executivas surge e se consolida. Na segunda parte, é realizada breve análise da presença de executivas em cargos de diretoria em empresas brasileiras do setor formal, no ano 2000, com base em dados do Ministério do Trabalho. Na terceira e última, são apresentados resultados de entrevistas realizadas com 10 executivas de empresas diversas do mercado de trabalho.
\end{abstract}

TRABALHADOR-MULHERES-DADOSESTATISTICOS-MERCADODETRABALHO

\section{ABSTRACT}

THE WORK OF EXECUTIVE WOMEN IN BRAZIL IN THE LATE $20^{\text {TH }}$ CENTURY. The article presents some comments on the work of executive women in Brazil during the late $20^{\text {th }}$ century. In the first section, based on official statistics (Census and Household Surveys, data from the Ministry of Labor, Ministry of Education and others), it presents some general trends of labor insertion of Brazilian women in that period, aiming at building the context in which the work of executive women emerged and was consolidated. The second part presents a short analysis of the presence of executive women in top level positions in Brazilian corporations of the formal economy, in 2000, based on data from the Ministry of Labor. The third and last section presents the results of interviews with 10 executive women of different corporations.

WORKERS - WOMEN - STATISTICAL DATA - LABOUR MARKET 
Este artigo tece considerações sobre o trabalho das mulheres executivas no Brasil, no final do século $X X$. Ele se compõe de três partes: na primeira, com base em estatísticas oficiais (Censos e Pesquisas Domiciliares, dados do Ministério do Trabalho, Ministério da Educação e outras), apresenta algumas tendências gerais da inserção laboral das brasileiras nesse período, visando compor o cenário no qual o trabalho das executivas surge e se consolida. Na segunda parte, é realizada breve análise sobre a presença de executivas em cargos de diretoria em empresas brasileiras do setor formal, no ano 2000, com base em dados da Rais/MTE! . Na terceira e última parte, são apresentados resultados de entrevistas realizadas com 10 executivas de empresas diversas do mercado de trabalho brasileiro².

\section{MULHERES E MERCADO DE TRABALHO NO BRASIL: FINAL DO SÉCULO XX}

As principais tendências a destacar, no que diz respeito à participação das brasileiras no mercado de trabalho, podem ser assim resumidas:

- A intensidade e a constância do aumento da participação feminina no mercado brasileiro, processo que ocorre desde a metade dos anos 70.

- A má qualidade do trabalho feminino, o qual predomina em atividades precárias e informais.

- A presença, a partir dos anos 80, de algumas tendências inovadoras, como a conquista de bons empregos, boas ocupações e acesso a profissões de nível superior, por parte de mulheres escolarizadas; entre elas, estariam executivas em empresas, como as estudadas neste texto.

- A mudança no perfil das trabalhadoras, desde os anos 80 - elas passam a ser mais velhas, casadas, com filhos, porém suas responsabilidades domésticas e familiares permanecem com sobrecarga.

I A Relação Anual de Informações Sociais - Rais - é uma base de dados do Ministério do Trabalho e Emprego - MTE - que fornece, anualmente, informações sobre número de empregos e algumas de suas características nas empresas do setor formal de atividade. Segundo essa base, estão computados na categoria de diretores os vários níveis de diretoria nas empresas, sendo impossível desagregar desse conjunto os postos de altíssimo escalão. Essa característica pode levar à superestimação das diretoras focalizadas neste artigo.

2 As entrevistas foram realizadas por Andrea Brandão Puppin. 
- A persistência da maternidade como geradora de dificuldades para o trabaIho das mulheres, quando os filhos são pequenos.

Indicadores gerais para o Brasil revelam que, no período 1990-1998, a População Economicamente Ativa $^{3}$ - PEA - feminina passou de 22,9 milhões para 3 I, 3 milhões, a taxa de atividade passou de $39,2 \%$ para $47,6 \%{ }^{4}$ e a porcentagem de mulheres no conjunto dos trabalhadores foi de $35,5 \%$ para $40,7 \%$.

Nas últimas décadas do século $X X$, o país passou por importantes transformações demográficas, culturais e sociais que tiveram grande impacto sobre o trabalho feminino: queda da taxa de fecundidade, sobretudo nas cidades e nas regiões mais desenvolvidas do país, de 4,4 filhos por mulher, em 1980, para 2,3 filhos no final da década de 90; redução no tamanho das famílias que, no final dos anos 1990, passaram a ter apenas 3,4 membros; envelhecimento da população brasileira, com maior expectativa de vida das mulheres e, conseqüentemente, aumento do percentual de viúvas na população; aumento do número de famílias chefiadas por mulheres que, no final do século, chegam a $26 \%$ do total das famílias brasileiras.

Além dessas transformações demográficas, mudanças nos padrões culturais e nos valores relativos ao papel social da mulher alteraram a identidade feminina, cada vez mais voltada para o trabalho produtivo. Ao mesmo tempo, a expansão da escolaridade e o ingresso nas universidades viabilizaram o acesso das mulheres a novas oportunidades de trabalho. Todos esses fatores explicam não apenas o crescimento da atividade feminina, mas também as transformações no perfil da força de trabalho desse sexo. As trabalhadoras, que até o final dos anos de 1970, em sua maioria, eram jovens, solteiras e sem filhos, passaram a ser mais velhas, casadas e mães. Em 1998, a mais alta taxa de atividade, superior a 66\%, é encontrada entre

3 Segundo classificação do Instituto Brasileiro de Geografia e Estatística - IBGE -, que realiza o Censo Demográfico, as Pesquisas Domiciliares Anuais e outras pesquisas oficiais, a População Economicamente Ativa inclui os ocupados e os desocupados. Os ocupados são aqueles que estão empregados, no setor formal ou no informal, enquanto os desocupados são aqueles que estão à procura de emprego na ocasião da pesquisa. Já a População Economicamente Inativa inclui os aposentados, os que estão em asilos, os estudantes e as donas de casa.

$4 \bigcirc$ aumento significativo de mulheres na PEA, nesse período, deve-se, em parte, a uma reformulação do conceito de trabalho realizada pela equipe da Pesquisa Nacional por Amostras de Domicílios - PNAD/IBGE -, no começo dos anos 90, que atingiu especialmente as mulheres, ampliando o número de trabalhadoras desde então. 
mulheres de 30 a 39 anos e cerca de $63 \%$ das de 40 a 49 anos também são ativas. Entretanto, apesar de todas essas mudanças, muita coisa continua igual: as mulheres continuam as principais responsáveis pelas atividades domésticas e cuidados com os filhos e demais familiares, o que representa uma sobrecarga para aquelas que também realizam atividades econômicas. Segundo dados da Pesquisa de Padrão de Vida, do IBGE, realizada em 1996-97, 79\% das mulheres se dedicam a afazeres domésticos e gastam neles cerca de 36 horas semanais. Em contrapartida, apenas $28,6 \%$ dos homens realizam atividades semelhantes e gastam nelas somente 14 horas por semana. A presença de filhos pequenos continua sendo um fator que dificulta a ocupação feminina. Em 1998, as taxas de atividade das mães são muito mais baixas quando os filhos têm menos de dois anos (47\%), ou mesmo entre dois e quatro anos (58\%), em comparação àquelas das mães de filhos maiores, que giram entre $62 \%$ e $65 \%$.

A expansão da escolaridade, à qual as brasileiras têm tido cada vez mais acesso, é um dos fatores de maior impacto sobre o ingresso das mulheres no mercado de trabalho. As taxas de atividade das mais instruídas (mais de I I anos de estudo) são muito mais elevadas do que as taxas gerais de atividade, em todos os anos analisados. Em 1998, a taxa feminina de atividade era de 47,5\%, mas a de mulheres com 15 anos ou mais de estudo era superior a $81 \%$. Além disso, as trabalhadoras têm escolaridade mais elevada do que os trabalhadores, reproduzindo o que ocorre na população de modo geral. Nesta, o predomínio feminino ocorre a partir do ensino médio (nove a II anos de estudo), no qual 55, I \% das matrículas são femininas. No ensino superior, as mulheres ampliaram sua presença na década, atingindo percentual superior a $61 \%$. No entanto, elas se concentram em determinadas áreas do conhecimento, como Lingüística, Letras e Artes (83\%), Ciências Humanas (82\%), Ciências Biológicas (74\%) e Ciências da Saúde (67,6\%), que as preparam para ocupar os chamados "guetos" femininos. Entretanto, a presença feminina nas universidades tem ultrapassado a dos estudantes também em redutos masculinos, como Administração, Arquitetura/Urbanismo e Direito.

Os dados referentes à ocupação da mão-de-obra brasileira na década de 90 sinalizam a persistência dos já conhecidos padrões diferenciados de inserção feminina e masculina, segundo setores ou grupos de atividades econômicas: pela ordem, os setores do mercado de trabalho nos quais as trabalhadoras continuam encontrando maiores oportunidades de trabalho e emprego são a prestação de serviços, o setor agrícola, o social, o comércio de mercadorias e a indústria. Nos serviços, setor com forte presença de mulheres, estavam ocupadas cerca de 30\% 
das trabalhadoras, em toda a década. Nesse setor houve, porém, ao longo desses anos, aumento da ocupação masculina, embora se tenha mantido em torno de apenas 10\%. Esse movimento teria como causas basicamente os processos de reestruturação produtiva e organizacional das empresas, a retração da indústria, tradicional reduto masculino, diante das sucessivas instabilidades econômicas, bem como a tendência à diminuição da importância do setor secundário da economia em favor de um terciário ampliado e diversificado.

O segmento mais protegido do mercado de trabalho, representado tradicionalmente pelo emprego com carteira de trabalho assinada, reduziu-se na década analisada. Em 1990, 59\% do total de empregados dispunham desse documento, mas, em 1998, o índice encontrado foi de 54\%. Desagregando essas proporções por sexo, verifica-se que os homens foram mais prejudicados que as mulheres, pois em 1990, 61\% dos empregados do sexo masculino tinham carteira assinada, enquanto em 1998 esse segmento cai para 54\%, graças a um processo de flexibilização do mercado que atingiu especialmente a indústria. Já as mulheres, mais concentradas no terciário, tiveram o registro em carteira reduzido de 55\% para 53,5\%.

A inserção das mulheres no mercado de trabalho brasileiro tem sido caracterizada através do tempo pela marca da precariedade, o que atinge importante parcela de trabalhadoras. Em 1998, nada menos que 36\% da força de trabalho feminina ou dez milhões de mulheres situavam-se em nichos precários do mercado de trabalho, seja como trabalhadoras domésticas, seja realizando atividades não remuneradas ou trabalhos destinados ao consumo próprio ou do grupo familiar. $\bigcirc$ emprego doméstico, ocupação feminina por excelência ( $90 \%$ de mulheres), absorve 17\% da força de trabalho feminina, mais de quatro milhões de mulheres, e esta ocupação é considerada precária em razão das longas jornadas de trabalho desenvolvidas pela maioria das trabalhadoras, pelo baixo índice de posse de carteira de trabalho e pelos baixos rendimentos auferidos. Em 1998, 76\% delas não possuíam carteira de trabalho e $88 \%$ ganhavam menos de dois salários mínimos por mês.

Em contraponto às ocupações precárias, mulheres instruídas, além de continuar marcando presença em tradicionais "guetos" femininos, como o magistério e a enfermagem, têm adentrado também áreas profissionais de prestígio, como a Medicina, a Advocacia, a Arquitetura e até mesmo a Engenharia, tradicional reduto masculino (Bruschini, Lombardi, 1999 e 2000). É neste pólo de mulheres instruídas que se situam também as executivas focalizadas neste texto.

No entanto, ainda que essas mulheres estejam ocupando novos e promissores espaços de trabalho, nos quais sua inserção tem características bastante simi- 
lares às dos homens, elas permanecem submetidas a uma desigualdade de gênero presente em todos os escalões do mercado de trabalho: ganham menos do que seus colegas de profissão.

Mulheres ganhando menos do que homens é uma situação recorrente não só no Brasil, mas em todo o mundo. Segundo a Organização Internacional do Trabalho - OIT (1997), para o período de 1991-1996, no Brasil, o rendimento recebido pelas mulheres em trabalhos não agrícolas correspondia a $72 \%$ daquele recebido pelos homens, enquanto na França o ganho feminino eqüivalia a $81 \%$ do masculino e no Japão, a 62\%. Se, na distribuição dos rendimentos dos trabalhadores e trabalhadoras brasileiros, considerarmos a influência da raça/cor, poderemos perceber, em primeiro lugar, a situação desfavorável dos trabalhadores negros no mercado de trabalho e, em segundo, a posição duplamente desfavorável das muIheres negras. Num contínuo decrescente de rendimentos, os brancos vêm em primeiro lugar, seguidos das brancas, dos negros e, finalmente, das negras. Este contínuo de desigualdade está presente em todo o país, sendo que as mulheres brancas estão sempre mais bem representadas do que as negras nos melhores empregos e nos setores mais organizados da economia, nos quais a probabilidade de obter salários mais elevados e melhores condições de trabalho é maior. No entanto, é preciso considerar que o Brasil é um país que apresenta enormes desigualdades regionais segundo o atributo raça/cor ${ }^{5}$.

As mais baixas remunerações recebidas pelas mulheres quando comparadas às dos homens são reafirmadas quando se consideram os setores econômicos, os grupos de horas trabalhadas, a posição na ocupação e os anos de estudo. Para citar um exemplo, em 1998, na indústria, em que as relações de trabalho são mais formalizadas, enquanto 37\% dos ocupados recebiam menos de dois salários mínimos, entre as ocupadas $49 \%$ se situavam na mesma faixa de renda. Na prestação de serviços, o setor que mais emprega mulheres, $76 \%$ delas se situava nessa faixa de rendimentos e apenas $41 \%$ dos ocupados. Em todas as situações analisadas, as

5 Segundo o Censo Demográfico de 2000, 53,7\% da população brasileira é branca e 44,7\% é negra (inclui pretos e pardos, categoria do IBGE que se refere a mulatos). Mas, enquanto nas regiões Norte e Nordeste do país predominam os negros (66\% no Nordeste e 69\% no Norte), no Sul e no Sudeste ocorre exatamente o inverso, com 62\% de brancos no Sudeste - região que inclui os Estados de Minas Gerais, Espírito Santo, Rio de Janeiro e São Paulo e 84\% de brancos no Sul - que inclui os Estados do Paraná, de Santa Catarina e do Rio Grande do Sul. 
desigualdades salariais repetem-se e constituem a marca indelével da discriminação que ainda paira sobre as trabalhadoras, apesar das conquistas. $O$ diferencial de rendimentos, segundo anos de estudo, reforça essa tese. Embora o nível de escolaridade feminino seja mais elevado que o masculino, na faixa superior a I 5 anos de estudo, $85 \%$ dos homens e apenas $67 \%$ das mulheres ganhavam mais de cinco salários mínimos ${ }^{6}$ em 1998. Não é diferente o que ocorre em cargos de diretoria das empresas brasileiras do setor formal. Nestas, no ano 2000, cerca de 60\% dos diretores ganhavam mais de 15 salários mínimos mensais ${ }^{7}$. Contudo, ao desagregar a informação por sexo, era possível constatar que, enquanto a grande maioria dos diretores do sexo masculino encontrava-se nessa situação privilegiada, o mesmo ocorria para um percentual muito inferior de diretoras, como é demonstrado nos dados do tópico seguinte.

\section{EXECUTIVAS EM CARGOS DE DIRETORIA EM EMPRESAS DO SETOR FORMAL $^{8}$}

No Brasil, dos 42.276 cargos de diretoria computados pela Rais ${ }^{9}$ no ano 2000, 23,6\% eram ocupados por mulheres. Ao analisar as empresas segundo o ramo de atividade, no entanto, verifica-se que os empregos femininos em nível de diretoria predominam em empresas de serviços comunitários e sociais, nas quais pouco mais da metade dos cargos desse nível eram ocupados por mulheres (Gráf. I).

6 Os dados estatísticos citados neste texto estão disponíveis no site http://www.fcc.org.br (Fundação Carlos Chagas, Banco de dados sobre o trabalho da mulher).

7 O salário mínimo mensal no Brasil era $R \$ 240,00$, inferior a $\cup \$ 100,00$, na data focalizada.

8 Os gráficos apresentados nesta seção e as tabelas que a eles deram origem foram elaborados, respectivamente, por Miriam Bizzochi e Maria Rosa Lombardi, da Fundação Carlos Chagas, às quais agradeço. Explicação: Na face esquerda, o gráfico de barras empilhadas possibilita ao leitor visualizar a participação de homens e mulheres no total de empregos para diretores para cada um dos ramos de atividade selecionados (ex.: "ramos de atividade" - Gráf. I e 2). Na face direita, o gráfico de barras agrupadas permite comparar a distribuição dos empregos ocupados por mulheres por ramo de atividade com a distribuição dos empregos ocupados por homens. Nesse gráfico, também é apresentada a distribuição para o total dos empregos por tipo de atividade. Vale observar que esta explicação cabe para as seis representações gráficas mostradas no decorrer do artigo. Nestas, os gráficos de barras são substituídos por gráficos de coluna e a variável ramo de atividade é substituída por seis outras que caracterizam: vínculo empregatício (Gráf. 3); tamanho do estabelecimento (Gráf. 4); faixa etária (Gráf. 5); tempo de emprego (Gráf. 6); grau de instrução (Gráf. 7); remuneração média mensal (Gráf.8).

9 Consultar nota 3. 


\section{GRÁFICO I \\ EMPREGOS PARA DIRETORES, SEGUNDO O SEXO E \\ RAMO DE ATIVIDADE DA EMPRESA}

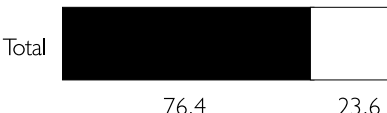

$\square$ Total $\quad$ Masculino $\square$ Feminino
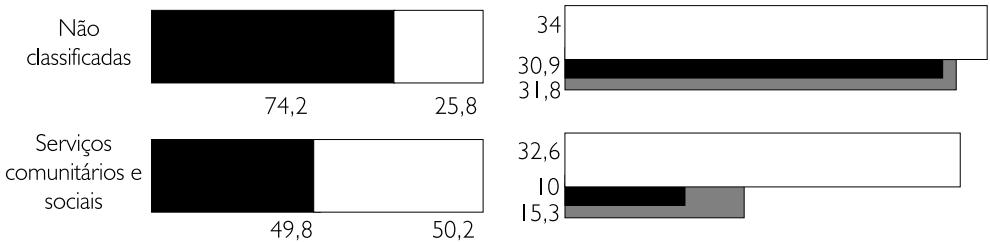

Financeiras
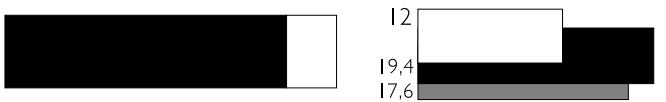

84

16

\section{Transporte e comunicação}
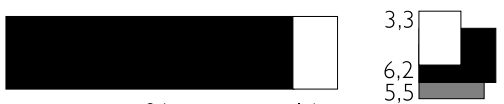

Atacadista,
varejista, emp.
hotel estab.

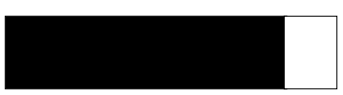

82,9

17,1

Construção
civil

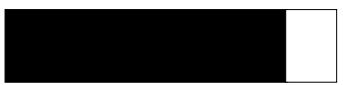

84,8

15,2

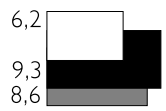

Prod. dist. energia elétrica gás e serv. ág.

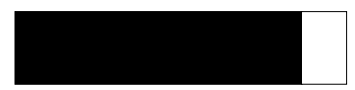

86,2

13,8

\section{Agropecuárias, pesqueiras e extrativas}

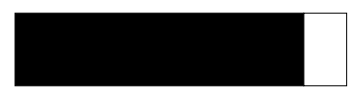

86,9

13,1

Manufaturas

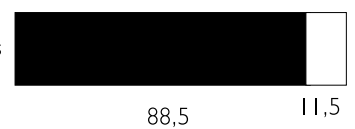

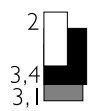
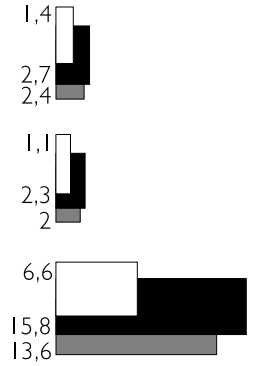

Fonte: Brasil, 2000. 
GRÁFICO 2

EMPREGOS PARA DIRETORES EM EMPRESAS DO RAMO SERVIÇOS

COMUNITÁRIOS E SOCIAIS, SEGUNDO O SEXO

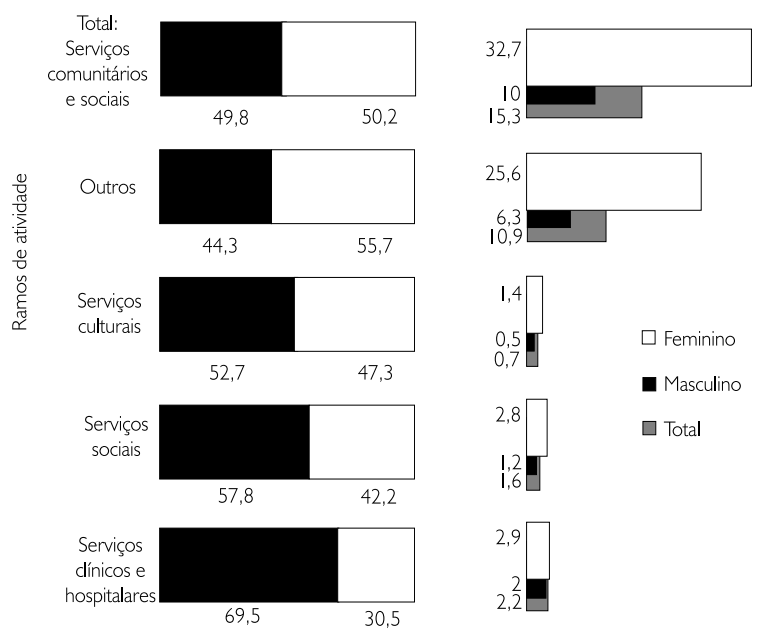

Fonte: Brasil, 2000.

Segundo a fonte utilizada, o grupo de empresas de serviços comunitários e sociais agrega as de serviços clínicos e hospitalares (30,5\% dos empregos de diretoria ocupados por mulheres), as empresas de serviços sociais (42,2\% dos cargos desse nível ocupados por mulheres), empresas de serviços culturais (47,3\%) e outras empresas do grupo, com 55,7\% das diretorias ocupadas por mulheres. Ou seja, é possível afirmar que os cargos de diretoria ocupados por mulheres apresentam-se em número elevado, ou até mesmo predominam, em áreas tradicionais femininas, como a social, a da cultura e a da saúde (Gráf. 2). Nos demais setores de atividade, a presença feminina em cargos de diretoria oscila de I I,5\% a 17\%.

Segundo tendência história, bem como dados de inúmeras outras pesquisas, as mulheres têm maior probabilidade de atingir posições mais elevadas na carreira dentro da administração pública, em comparação ao setor privado. Um bom exemplo é apresentado em uma pesquisa da Escola Nacional de Administração Pública Enap -, segundo a qual a proporção de mulheres em diretorias na Administração 
Pública Federal, em 1998, era de 44\%. A maioria delas, no entanto, encontrava-se nos ministérios considerados de missão social (Cultura, Educação, Saúde, Previdência e Assistência Social). A mesma pesquisa indicou que, naquele ano, cerca de $40 \%$ dos ocupantes dos cargos em comissão (mais elevados e decisórios) eram do sexo feminino.

Os dados da Rais/2000 analisados para este texto confirmam tal tendência, ao revelar que, enquanto no setor privado, $21 \%$ dos cargos de diretoria são ocupados por mulheres, o mesmo ocorre em 44,8\% dos cargos de mesmo nível no setor público (ver Gráf. 3).

\author{
GRÁFICO 3
}

EMPREGOS PARA DIRETORES, POR TIPO DE VÍNCULO, SEGUNDO O SEXO
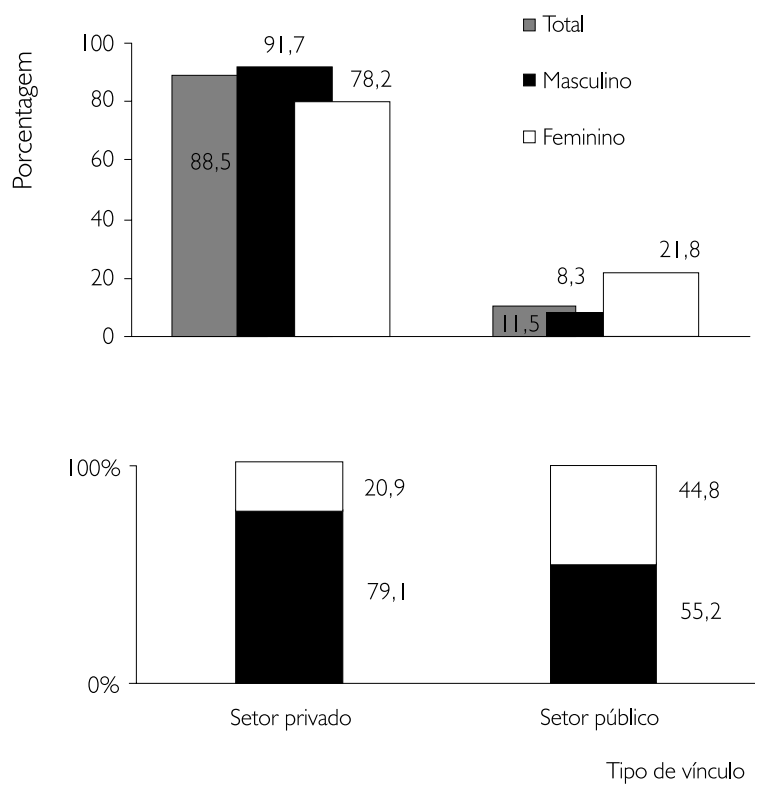

Fonte: Brasil, 2000. 
Alguns de nossos estudos sobre o trabalho feminino, em geral (Bruschini, 2000), permitem-nos levantar hipóteses em relação à presença feminina em postos de diretoria de empresa. A primeira delas é que as diretoras predominariam em empresas de médio ou pequeno porte, em comparação com as maiores empresas. Não foi porém o que constatamos ao analisar as informações da Rais/2000, pois estas revelam que as diretoras predominam em empresas de maior porte, com 250 empregados ou mais, nas quais atingem quase 30\% dos postos (Gráf. 4). Outra suposição, neste caso, com base em nossos estudos sobre a presença feminina em ocupações de prestígio, é que as diretoras seriam mais jovens do que os colegas em cargo similar e estariam no emprego há menos tempo do que eles. Essa tendência foi constatada por nós entre as arquitetas, médicas, advogadas e engenheiras analisadas a partir da mesma base de dados (Bruschini, Lombardi, 1999 e

\author{
GRÁFICO 4 \\ EMPREGOS PARA DIRETORES POR TAMANHO DO \\ ESTABELECIMENTO, SEGUNDO O SEXO
}
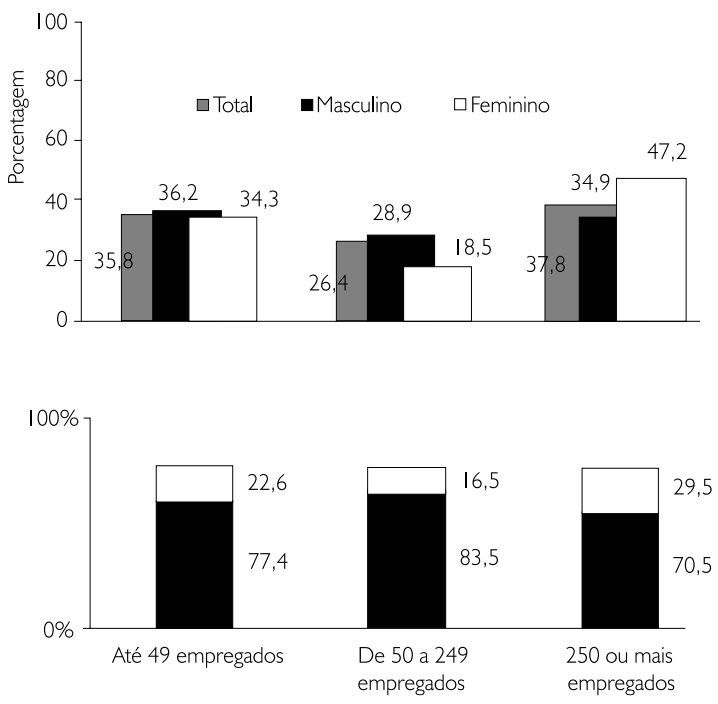

Tamanho do estabelecimento

Fonte: Brasil, 2000. 
2000), bem como em pesquisas não acadêmicas, como a do Grupo Catho, empresa de colocação no mercado de trabalho. Uma pesquisa desse Grupo ${ }^{10}$, com 380 mil executivos e 62 mil empresas, mostrou que as mulheres aumentaram sua participação entre os executivos de nível elevado, no final da década de 90, mas ainda eram maioria nos cargos mais baixos (Tab. I).

TABELA I

PARTICIPAÇÃO DE MULHERES NA OCUPAÇÃO DE CARGOS

\begin{tabular}{l|c|c}
\hline Cargo & $\begin{array}{c}\text { Mulheres \% } \\
1995\end{array}$ & $\begin{array}{c}\text { Mulheres \% } \\
1997\end{array}$ \\
\hline $\begin{array}{l}\text { Presidente, Executivo principal, } \\
\text { Gerente geral ou equivalente }\end{array}$ & 8,1 & 10,4 \\
\hline Diretor & 13,2 & 13,6 \\
\hline Gerente & 12,4 & 15,6 \\
\hline
\end{tabular}

Fonte: Grupo Catho (vide nota 10).

A mesma pesquisa mostrou que as mulheres estavam atingindo cargos mais elevados a partir da segunda metade da década de 90, com idades inferiores às dos colegas do mesmo nível (Tab. 2).

TABELA 2

MEDIANA DA IDADE PARA EXECUTIVOS ATINGIREM CARGOS DE NÍVEL ELEVADO NA DÉCADA DE 90, PÓS-PLANO REAL

\begin{tabular}{l|c|c}
\hline \multirow{2}{*}{ Cargo } & \multicolumn{2}{|c}{ Idade mediana para atingir o cargo pós-Plano Real } \\
\cline { 2 - 3 } & Homens & Mulheres \\
\hline Presidente & 44,2 & 37,1 \\
Diretor & 41,7 & 36,9 \\
Gerente & 38,4 & 33,7 \\
\hline
\end{tabular}

Fonte: Grupo Catho (vide nota 10).

10 Informação extraída do site www.catho.com.br (acesso: jul. 2000), visando ao levantamento de dados para uma palestra. 
No caso da idade e do tempo no emprego, a mesma tendência se confirma neste trabalho, uma vez que as diretoras são mais jovens do que os diretores e estão há menos tempo no cargo do que eles. Em 2000, observa-se, ao agregar as faixas etárias até 29 anos e de 30 a 49 anos, que mais de $80 \%$ das diretoras, e apenas 64\% dos diretores, tinham menos de 50 anos (Gráf. 5); além disso, 47\% delas, e apenas 44\% deles, estavam no emprego há menos de três anos (Gráf. 6).

Em contraposição, não se confirmou neste estudo nossa hipótese referente ao nível de escolaridade dos empregados. Esta era a de que as diretoras teriam mais estudo do que os diretores, uma vez que, para atingir cargo tão elevado quanto o de diretoria, a mulher deveria sobressair-se em relação ao colega do outro sexo, o que poderia ocorrer por meio da escolaridade. No entanto, não foi isso o que se observou, pois, embora a escolaridade de nível superior completo, provavelmente requisito para a ocupação de cargo tão elevado, predomine para ambos os sexos, o percentual de diretores com esse nível de estudo é mais elevado do que o de

\section{GRÁFICO 5}

EMPREGOS PARA DIRETOR PELA FAIXA ETÁRIA, SEGUNDO O SEXO
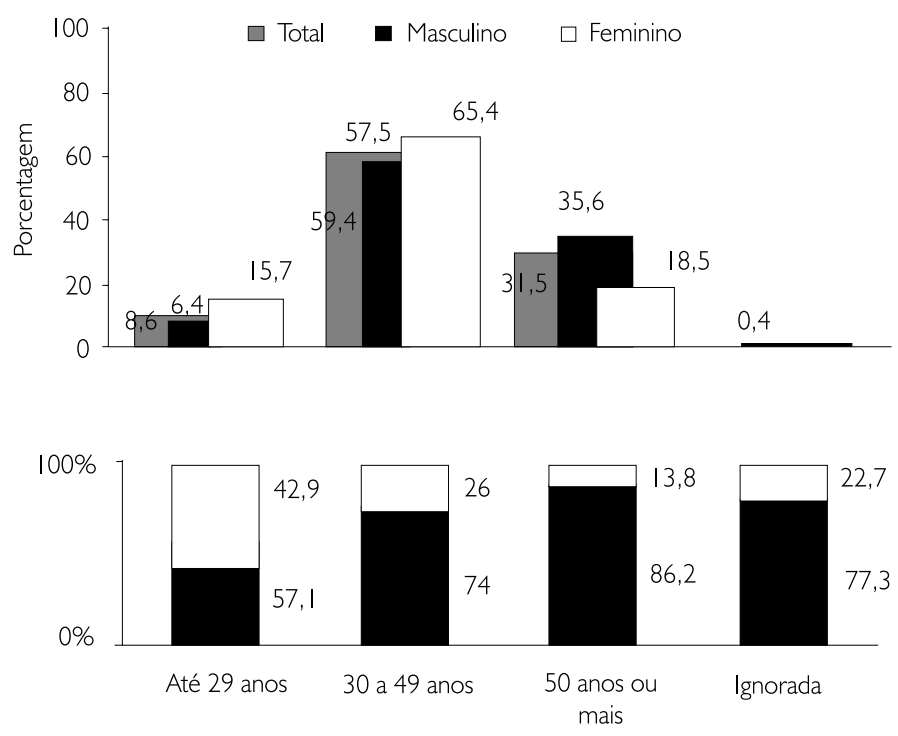

Fonte: Brasil, 2000.

Faixa etária 
GRÁFICO 6

EMPREGOS PARA DIRETOR POR TEMPO NO EMPREGO, SEGUNDO O SEXO
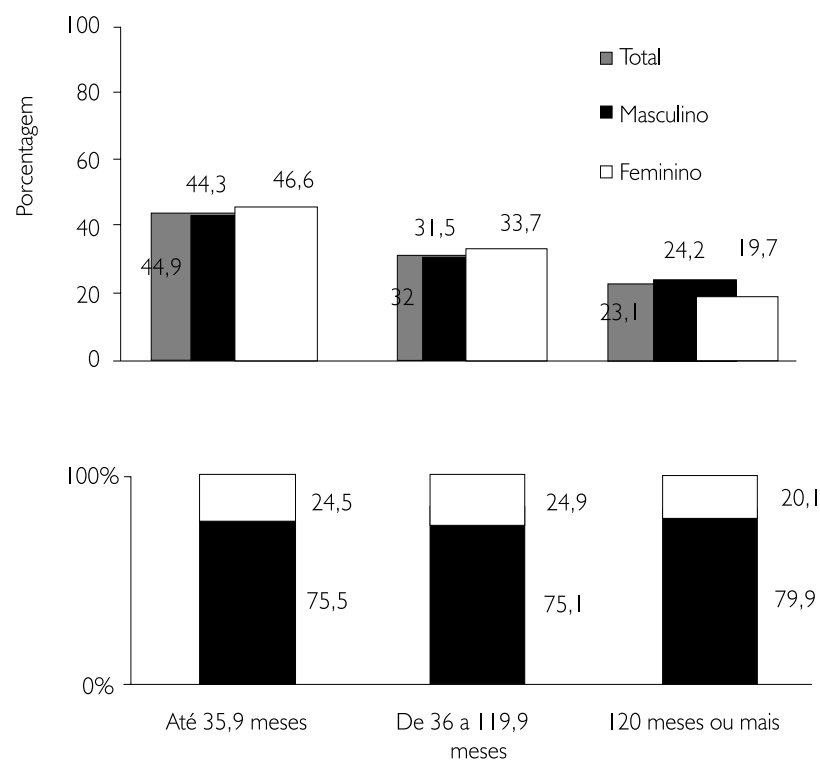

Tempo no emprego

Fonte: Brasil, 2000

diretoras (Gráf. 7). Além disso, o nível de rendimento deles é mais elevado do que o delas, como ocorre no mercado de trabalho em geral. Em primeiro lugar, como seria de se esperar, a remuneração em empregos nos níveis elevados em empresas do setor formal é muito maior do que a recebida por trabalhadores de níveis ocupacionais mais baixos. Segundo os dados analisados nesse caso, os diretores das empresas ganhavam, no ano 2000, mais de I 5 salários mínimos ou não declaravam seus salários (categoria "ignorado"). Em segundo lugar, como acontece em todas as situações analisadas pela literatura sobre o tema, inclusive em carreiras profissionais de prestígio (Bruschini, Lombardi, 2000), o diferencial de gênero também pode ser constatado entre os diretores das empresas brasileiras, nas quais quase $70 \%$ dos diretores, mas pouco mais de $30 \%$ das diretoras recebem remuneração média mensal superior a 15 salários mínimos (Gráf. 8). 


\section{GRÁFICO 7}

EMPREGOS PARA DIRETORES POR GRAU DE INSTRUÇÃO, SEGUNDO O SEXO
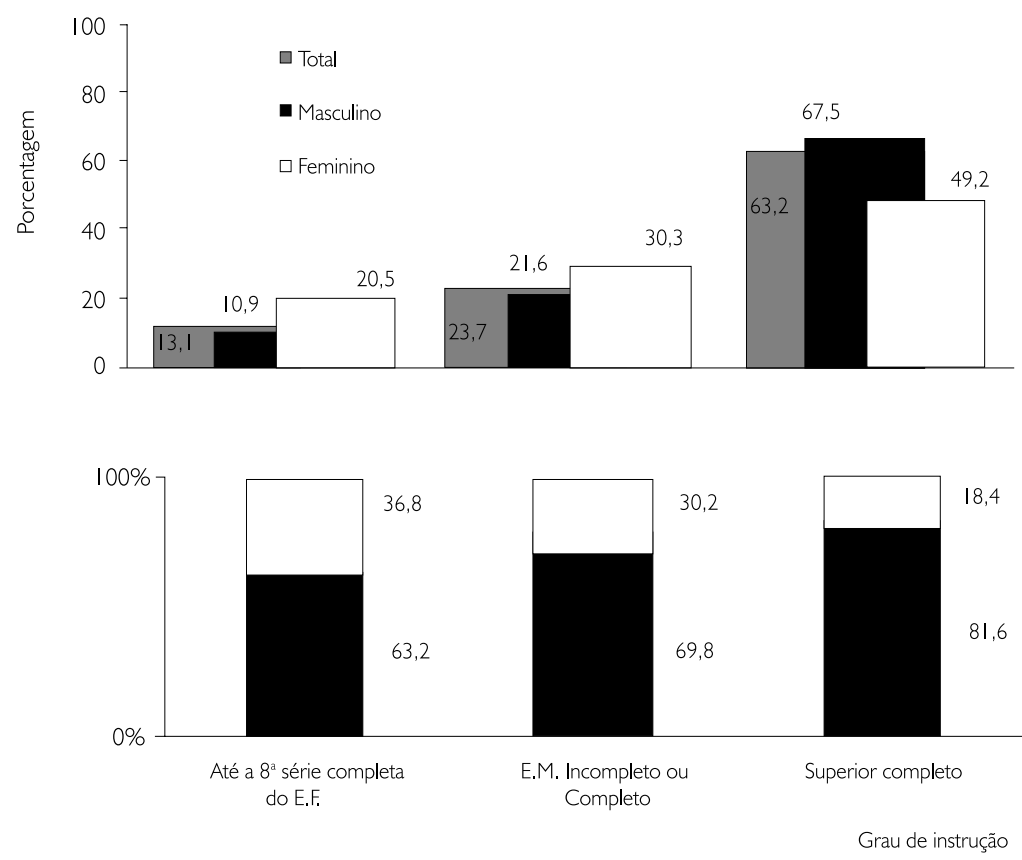

Fonte: Brasil, 2000.

Em suma, os dados revelam que, no Brasil, cerca de 24\% dos cargos de diretoria são ocupados por mulheres, percentual mais elevado do que o esperado, à luz dos estudos sobre o trabalho feminino que enfatizam os obstáculos encontrados pelas trabalhadoras para ter acesso a cargos de chefia. Entretanto, os dados mostram também que esses cargos se concentram em áreas tradicionais femininas, como a social, a cultural e a da saúde. Ou seja, mesmo nos níveis mais elevados da carreira, as executivas brasileiras marcam presença sobretudo em tradicionais guetos femininos. Elas são mais jovens do que os diretores, estão há menos tempo do que eles na diretoria e predominam em empresas de maior porte. Tem nível superior de escolaridade, porém, apesar do alto cargo ocupado, recebem rendimentos inferiores aos de seus colegas diretores. 


\section{GRÁFICO 8}

EMPREGO PARA DIRETOR PELA FAIXA DE REMUNERAÇÃO MÉDIA, SEGUNDO O SEXO
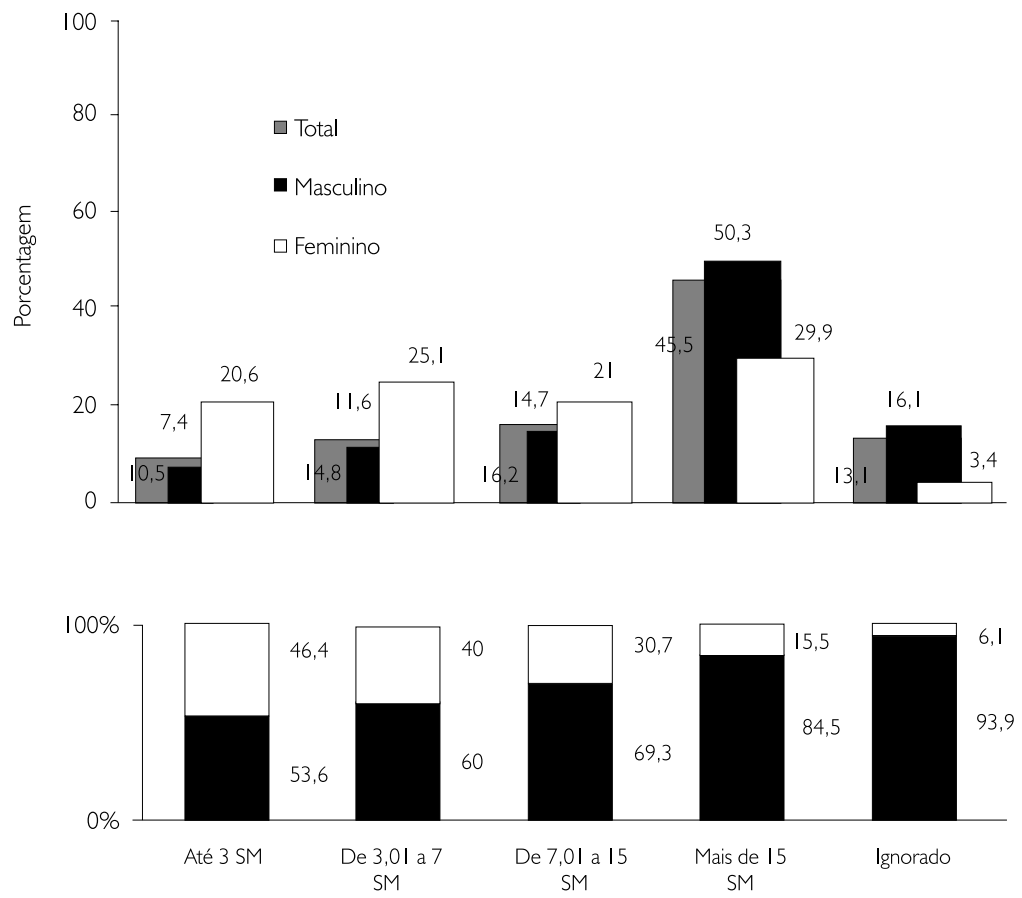

Remuneração média mensal

Fonte: Brasil, 2000.

O tópico seguinte ilustra, por meio de entrevistas com dez executivas brasileiras, algumas dessas características observadas entre diretoras do segmento formal do mercado de trabalho brasileiro no ano 2000.

\section{O QUE DIZEM ALGUMAS EXECUTIVAS}

Apesar do pequeno número, as entrevistas permitiram contar com relatos de executivas de uma gama variada de empresas: do setor público e do privado; de pequenas, médias e grandes empresas; de empresas nacionais e de multinacionais; de setores variados, como banco, editora, transportes, petróleo, empresa farma- 
cêutica, de cosméticos, de telefonia, de distribuição de refrigerantes. Foram entrevistadas executivas de áreas de comando em nível de gerência ou superior, em setores diversos das empresas, como recursos humanos, diretoria comercial, diretoria de produção, diretoria de marketing, gerência de desenvolvimento de sistemas, gerência do departamento de informações, gerência de aquisição e desenvolvimento de talentos, diretoria editorial, gerente de administração de recursos humanos, setor administrativo (contabilidade, por exemplo), gerência intermediária, gestão de pessoal, gerência de vendas, marketing, diretoria de recrutamento e seleção, finanças, tesouraria, transporte e guarda de valores, operações, assessoria jurídica, áreas técnicas, assessoria sindical e trabalhista, chefia de pessoal e diretoria financeira. As entrevistas versaram sobre os seguintes temas: presença da mulher em cargos executivos; percepção do nível salarial entre mulheres e homens; fatores que influenciam na promoção de mulheres a cargos de gerência e/ou diretoria; relação entre a educação e promoção; funções desempenhadas pelas mulheres; opiniões sobre a cultura corporativa; processo de recrutamento e contratação; opiniões sobre como o papel tradicional das mulheres no país afeta a mulher executiva. Foram investigadas também opiniões das executivas sobre organizações que se destacam por sua promoção de mulheres a cargos de gerência, sobre programas formais de corporações que promovem o crescimento profissional de mulheres e sobre política de cotas e de diversidade. Outros temas, como exigência diferencial de desempenho de mulheres com relação aos homens e identificação de estilos de liderança femininos e masculinos foram também abordados. A seguir, algumas dessas entrevistas são apresentadas. Embora tenham sido incluídas também entrevistas com gerentes, foram selecionadas, preferencialmente, entrevistas com executivas em nível de diretoria, a fim de conferir ao texto uma relativa unidade entre o primeiro e o segundo tópico. As entrevistadas são executivas das seguintes empresas:

- Xerox - empresa de equipamentos multinacional - há uma diretora à frente de sete diretores (segundo escalão). A presidência é masculina. Os homens na empresa são 2.206 (74,2\%) e as mulheres, 766 (25,8\%). As mulheres apareceram no escalão de diretoria apenas de oito anos para cá.

- Banco do Brasil - empresa nacional estatal - na qual há 50.866 homens e 27.494 mulheres, mas não há mulheres dentre os 13 diretores.

- Wella - empresa de cosméticos - com 666 empregados, sendo 372 muIheres. No primeiro escalão - presidência e três vice-presidentes - não há 
mulheres, mas na diretoria há uma mulher entre os cinco diretores, na área de marketing para a América Latina.

- Indústria Gross - farmacêutica de pequeno porte - com 204 empregados, sendo I 23 homens e 81 mulheres. A empresa conta com um cargo de presidência e três cargos de diretoria, sendo um destes ocupados por mulher, da área industrial.

- Editora Record - empresa nacional - com 183 funcionários, 40\% dos quais do sexo feminino. Dos cinco cargos de direção dois são preenchidos por mulheres, diretoria comercial e diretoria de produção.

- Coca-Cola Company - empresa que trabalha com sistema de franquia autoriza engarrafadores a produzirem, distribuírem e venderem os produtos Coca-Cola: conta com 14 diretores e duas diretoras.

- Texaco - multinacional de petróleo - com mais de mil funcionários, tem apenas uma mulher no escalão de diretoria, a de recursos humanos.

- ATL - empresa de telefonia - com 1.537 funcionários, sendo a maioria mulheres: 923 (60\%). No escalão de diretoria, porém, esse percentual é escasso: três mulheres (18\%) para 14 homens (82\%).

A seguir, as opiniões das executivas (diretoras e algumas gerentes) entrevistadas em relação aos seguintes temas:

\section{Presença da mulher em cargos executivos}

Para a gerente de desenvolvimento de sistemas da Texaco, foi fundamental a ajuda de um mentor e a própria competência pessoal. Ela foi uma das primeiras mulheres a ingressar em cargo gerencial, o que ocorreu em 1986, na coordenação de desenvolvimento de sistemas, em uma equipe só de homens.

Houve um certo estranhamento, pois eu só tinha dois anos de casa, com trinta e poucos anos... Não encontrei grandes barreiras por ser mulher, a minha competência sobrepujou. Antes da Texaco trabalhei numa consultoria em que determinados clientes - órgãos de governo - estranhavam ver uma jovem consultora ("Ih, mandaram para cá uma menina!") porque não estavam acostumados, pois os quadros eram todos masculinos. Falavam gracinhas, mas rapidamente eu provava que era capaz de dar conta... 


\section{Recrutamento e contratação}

Na visão das executivas entrevistadas, há muita concordância em relação à política de contratações da empresa. Cláudia, diretora de recursos humanos da L'Oréal, diz que "Na política de contratações da empresa, é indiferente o fato de ser mulher ou homem, mas há setores que atraem mais mulheres". A gerente da Xerox, entrevistada, acha que a empresa não tem preferência na hora de escolher um homem ou mulher: "O banco de contratações depende muito do que você está buscando. Se você está buscando um gerente de negócios, vai buscar no mercado; mas se você quer um analista e há estagiários com competência, você vai lançar mão dos estagiários..."

A coordenadora de remuneração da ATL, Silvana, dá seu depoimento:

Antes daqui, trabalhei também cinco anos na empresa Arthur Andersen. Não vejo discriminação no processo seletivo dessas duas empresas. Pode existir de forma escamoteada, mais invisível. A grande discriminação que poderia existir seria em razão da gravidez (no mercado de modo geral). Mas não aqui na ATL onde no setor de vendas existem três grávidas e o processo seletivo indicou outras três mulheres (eram as melhores candidatas).

A gerente da Texaco aponta que,

... se o pessoal de recrutamento e seleção não tiver uma diretriz de imparcialidade com relação a sexo e cor, pode atrapalhar muito a vida das mulheres ou minorias. Mas essa coisa de separar vaga para minorias eu acho um absurdo, não prova a capacidade de ninguém. Se uma mulher negra entra pelo sistema de cotas sem ser mais capacitada, é injusto para com os outros. Investir para que as minorias se capacitem no nível dos estudos, desde o ensino fundamental... aí é outra coisa. Na universidade as pessoas têm de ter base. É assim que se ajuda a uma minoria, dando condições de ela crescer.

No Banco do Brasil, como lembra a gerente entrevistada, a seleção se dá por concurso público:

Aqui no banco o recrutamento é feito por concurso público, no qual um grande contingente de mulheres é aprovado. A cada concurso vai aumentando o número delas, assim como a passos lentos sua ascensão na hierarquia do banco. As mulhe- 
res fazem escolhas de carreira: uma gerência média permite conciliar melhor os papéis pessoais e profissionais do que uma gerência geral.

Também a Flumitrens, outra empresa estatal, só conta com empregados concursados.

Luciana, diretora editorial da Record, acha que a questão do recrutamento é variável.

Uma empresa familiar de médio porte como a Record funciona diferentemente de um jornal, por exemplo. Aqui não há uma diretoria ou gerência de recursos humanos - há uma chefia de pessoal subordinada à diretoria financeira. Na minha área eu preferi recorrer ao meu capital social de conhecidos do que buscar um profissional anônimo no mercado. Também é comum contratar estagiários, independente do sexo do candidato.

Valéria, gerente das Indústrias Gross, vê como problemático o processo de recrutamento e seleção:

Às vezes encontra-se o preconceito nas resistências à contratação de mulheres. Mas isso depende... há lideres que preferem trabalhar com mulheres... outros, com homens. Depende muito da atividade a desenvolver... Recentemente contratei um auxiliar de almoxarifado que precisava usar da força física. No supermercado nunca admitimos mulheres como carregadores... Quanto à política de cotas, reserva de vagas para as minorias, sou contra. Para mim, você tem de ser contratado e promovido por competência, por qualificação, não interessa se você é homem ou mulher. Sou contra cotas para negros e mulheres.

\section{Promoção}

A idéia de que a empresa exerce uma "meritocracia" aparece bem estampada no depoimento da gerente de aquisição e desenvolvimento de talentos da Coca-Cola:

Na hora de promover uma pessoa, seja homem ou mulher, o que conta é a competência. Não tenho essa visão do que ajuda a mulher ou o homem. O que ajuda uma pessoa é a competência dela - estar pronta ou não para uma promoção e ser melhor que os outros candidatos. Sendo homem ou mulher o critério vai ser o mesmo: a competência... 
Essa idéia acerca da carreira e do trabalho na empresa é compartilhada por várias das entrevistadas, é um aspecto da ideologia meritocrática que presidiria os processos de ascensão hierárquica, percebidos como resultantes da premiação objetiva dos "melhores", idéia ligada ao pressuposto da "igualdade de oportunidades". A ascensão é vista como conseqüência "natural" da conquista de espaços, consideração que aparece nos depoimentos que recusam propostas de políticas protecionistas do tipo "discriminação positiva", como a determinação de um número mínimo de vagas a serem preenchidas por mulheres.

A gerente de recursos humanos das Indústrias Gross também adere a uma percepção meritocrática da companhia:

Escolher um profissional que vai exercer uma função de gestor implica competência: saber fazer, saber por que faz e saber liderar uma equipe: competência em cima de resultados... Um percentual de homossexuais, de mulheres, de negros eu acho ridículo. As pessoas devem assumir os cargos por competência, independentemente da sua condição minoritária.

[Para a gerente regional da área de Gestão de Pessoas do Banco do Brasil, outros fatores entram em pauta para facilitar ou dificultar promoções a cargos executivos: a disponibilidade para viagens:]

"Como a empresa é muito grande, a gente percebe que quando você tem mais disponibilidade para se locomover, suas chances de galgar cargos mais relevantes são maiores. Pois nossa sede não é no Rio de Janeiro, é em Brasília, onde estão os cargos de direção geral. Quando você aceita locomover-se a proposta de promoção fica mais fácil. E isso para a mulher é mais difícil - pois ela pode ser casada, ter filhos, aí não depende só dela: ou vai sozinha ou espera que o marido mude de estado... Não existe discriminação no sentido estrito, mas as promoções ocorrem com mais facilidade para aqueles que têm mais chances de se locomover. Os cargos têm muito a ver com disponibilidade, pois formação hoje em dia as mulheres têm tanta (se não até mais) quanto os homens (cursos, capacitação). Estar disponível 24 horas por dia implica em atualização e menor convívio com os filhos. Estar em eventos, reciclar-se, viajar, é difícil para quem tem filhos pequenos. Eu só entrei na carreira mais firmemente (cargo comissionado ) depois que meu filho cresceu. Os fatores mobilidade e disponibilidade, capacitação e compromisso são importantíssimos".

Para a diretora editorial da Record é um conjunto de fatores que contribuem para a seleção de mulheres em cargos executivos: trabalho duro, mentores, educação, designação a posto específico de trabalho, a cultura corporativa: 
É um pouquinho de cada coisa. O trabalho duro, não resta a menor dúvida. Mentores... é o caso da sorte de estar no lugar certo na hora certa (principalmente nos casos de quebra de paradigma). A educação é um pré-requisito principalmente em áreas técnicas. A cultura corporativa pesa na empresa grande. Na empresa pequena você é aquilo que produz... $\bigcirc$ mérito fica muito mais visível na pequena empresa: eu fui trabalhar na empresa de consultoria e cresci muito rápido por causa disso - o ruim é que o teto chega muito rápido e você não tem mais para onde subir!

Para a gerente da Wella - empresa de cosméticos -, a formação é fundamental. Mas também a cultura corporativa:

... pois eu acho que existe o preconceito. Você veja nessa empresa... uma diretora de marketing... o pessoal já fica assim... estranham. Você não vê muitas mulheres em cargos executivos de primeira linha. Normalmente quando vê acha que tem de ser aquela "dama de ferro", tem de ser aquela "durona". Eu sinto isso, parece que ela tem de se impor mais - parece que para o homem é mais natural ele ser um executivo - a mulher não: tem de ser durona, tem que se impor, tem de se colocar, tem de mostrar que é melhor. Eu percebo isso.

\section{Percepção do nível salarial entre mulheres e homens}

Todas as entrevistadas foram unânimes em afirmar que não há diferenças salariais para os mesmos cargos.

O que existe são posições melhor ocupadas pelos homens, que estão há mais tempo no mercado, por isso ganham mais - por estarem mais bem colocados, dizem algumas. Na Editora Record, uma exceção: os dois salários mais elevados (das Diretorias Comercial e de Produção) são de mulheres.

\section{Relação entre educação e promoção}

Todas as executivas assumem a educação como importante : "A educação é pré-requisito para qualquer profissional que deseje galgar os respectivos níveis do nosso quadro funcional... Temos em nossos quadros desde empregados de via permanente até empregados com doutorado, com cursos fora do país" (Sebastiana S., Flumitrens). 
A educação avulta como um pré-requisito, principalmente em áreas técnicas. A titulação é mais importante hoje do que no passado. Fui fazer MBA I' aos sábados na Fundação Getúlio Vargas. Hoje em dia as mulheres entram no mercado até para complementar a renda masculina que foi achatada... e se inserem com níveis educacionais superiores aos dos homens... (Telma, Texaco)

Cláudia, diretora da L'Oréal, dá o seu depoimento: "Conta aqui a titulação, você ter uma excelente formação acadêmica influencia no acesso aos cargos mais elevados, abre portas. Para isso é preciso ter cursado faculdades de primeira linha no Brasil ou no exterior, ter feito Master of Business Administration..."

\section{Funções desempenhadas pelas mulheres nas empresas}

A pesquisa constatou que, mesmo entre executivas de nível elevado, há uma divisão sexual do trabalho, pois elas se concentram em determinados setores das organizações e não em outros. Na Texaco, por exemplo, elas são encontradas no setor de recursos humanos e na área administrativa de um modo geral, porém são inexistentes no setor industrial propriamente dito.

No Banco do Brasil, existem muitas mulheres na gerência média que, ao exigir do ocupante pouca movimentação em termos de viagens, tende a facilitar a conciliação entre interesses profissionais e privados. A gerente entrevistada chama a atenção para um percentual muito elevado de mulheres na área de recursos humanos, predominantemente ocupada por mulheres com formação em Psicologia, Pedagogia, Assistência Social, ou seja, formações predominantemente femininas. Sobre o mesmo tema, outra entrevistada reportou-se a Domenico di Masi ${ }^{12}$, que

... esteve aqui fazendo uma palestra, na qual situou o setor de Recursos Humanos como um prolongamento da maternidade, no qual se faz a gestão de coisas e idéias que vão facilitar as pessoas... Quando se faz um curso de pós-graduação em R.H. encontramos $80 \%$ de mulheres - uma incidência muito grande na área.

Na L'Oréal, empresa que atrai muitas mulheres, por sua especialidade cosméticos, beleza -, existem cargos que só podem ser ocupados por mulheres.

I I Master of Business Administration, como é denominado o mestrado na área de administração.

12 Sociólogo italiano contemporâneo, autor de livros sobre o tempo do trabalho, o lazer e o ócio na sociedade capitalista, tema sobre o qual também faz palestras. 
Maquillage por exemplo, existe uma atração "natural" de mulheres trabalhando com esse tipo de produto. A área de marketing, na qual você tem que falar com o consumidor final, também atrai as mulheres. Segundo Cláudia, diretora de recrutamento e seleção, essas áreas exigem pessoas sensíveis, "uma sensibilidade que está muito presente nas mulheres, que têm intuição".

Na Flumitrens, a diretora de recursos humanos dá uma noção sobre a distribuição de mulheres pelas funções da empresa:

... dos 1.600 funcionários, temos $20 \%$ na área administrativa, dos quais 100 são mulheres. A mulher tem uma participação muito direta, principalmente naquelas áreas que lidam mais diretamente com o ser humano - porque desenvolve com mais sensibilidade, com mais cuidado o relacionamento com os empregados. Contudo, isso não significa que elas não participem das áreas técnicas. Nós temos diversas colegas no setor de telecomunicações. Temos a área de Recursos Humanos (50 mulheres e 15 homens), de Finanças (20 mulheres, englobando a contabilidade e 25 homens abarcando a tesouraria, transporte e guarda de valores. Na área de operações a mulher está presente na parte de orçamento da empresa ( 15 mulheres) e nas assessorias jurídicas da empresa (duas mulheres para seis homens). No restante, teríamos a participação gerencial nas áreas técnicas (dez engenheiras para 230 engenheiros). E há uma assessoria sindical e trabalhista (duas mulheres e um homem).

\section{Cultura corporativa}

As respostas à pergunta se a cultura da empresa contribui ou cria barreiras à promoção de mulheres a cargos executivos foram variadas. Para Silvana, da ATL, a cultura corporativa cria barreiras, pois, na sua opinião, é essencialmente machista:

Nossa inserção no mercado de trabalho é mais recente que a dos homens. Já há uma cultura estabelecida, mas ela se dilui no caso de empresas mais novas. A cultura sendo machista dificulta as promoções, sim... não é uma coisa racional, é cultural mesmo, então implica em uma certa dificuldade para as mulheres. Outro dia estava lendo o Domenico di Masi, que disse que haverá igualdade entre homens e mulheres no dia em que se encontrar uma mulher executiva em alta posição de direção, sendo incompetente - pois homens incompetentes em posição de comando ele vê vários, mulher não - tem de ser competente. 
No Banco do Brasil, a gerente entrevistada deu o seguinte depoimento acerca da grande mudança que se fez na cultura corporativa a partir dos anos 70:

... antes dessa data era proibida a presença feminina! Hoje temos um maior número de mulheres entrando por concurso. A cultura machista vai se diluindo. Cada vez mais o estilo de gestão que a maioria das mulheres tem, se masculiniza por causa da estrutura machista. Mandar, fazer respeitar, não chorar - são tradições masculinas. Os cargos mais importantes ainda são ocupados pelos homens.

Ângela, gerente da Wella, acha que a cultura corporativa da sua empresa mais prejudica do que auxilia as mulheres:

... Em alguns casos há chacota. Afinal a mulher "é o sexo frágil", e se ela atingiu o topo é porque ela é diferente. No nível de gerente acho que o pessoal está mais acostumado (desde 1980 as mulheres têm-se destacado nas gerências), mas no nível de diretoria não! A cultura corporativa favorece os homens a se manterem nessas posições.

Outra executiva que vislumbrou uma cultura machista em sua empresa foi Telma, da empresa de petróleo Texaco:

No passado, havia uma cultura machista da época, que incluía desde chacotas às paqueras sem conseqüência. É claro que onde há homens e mulheres há formação de pares, e a Texaco tem vários pares casados - mas é proibida a relação vertical chefe/subordinado - quando isso ocorre um dos dois é transferido de área... Sobre os preconceitos contra as mulheres, tínhamos que fazer o dobro deles para provar que éramos boas de trabalho.

Um exemplo de elemento cultural preconceituoso foi mencionado pela gerente de recursos humanos das Indústrias Gross:

Preconceito com relação à maternidade. Todas as entrevistas que fiz procurando emprego sondaram ou foram explícitas com relação à predisposição em ter filhos. Uma amiga recebeu a informação de que não foi contratada porque o cargo implicava viagens e ela tinha filho pequeno... O preconceito hoje em relação à mulher não está na competência não, mas nos quatro meses de afastamento na gravidez e em relação aos problemas que a maternidade gera, como o acompanhamento dos fiIhos. 
Na L'Oréal, a diretora de recrutamento e seleção acha que a cultura corporativa influencia bastante:

...empresas mais tradicionais ou machistas não vão dar às mulheres cargos-chave. Mas acredito que contra a competência não há argumento, e para isso há de se conseguir um equilíbrio entre o lado familiar e o profissional. A mulher tem sempre de dar algo a mais que o homem. Mostrar que realmente nossa vida pessoal não está influenciando nosso dia-a-dia de trabalho, mostrar que não somos frágeis - são elementos que alteram uma cultura corporativa tradicional.

A gerente da empresa Xerox diz que "...ser receptivo ou não à mulher é uma decisão que normalmente vem de cima. A receptividade tanto no board(conselho, nível mais alto) quanto nos demais níveis começa a acontecer quando se percebe a lisura e a competência no trabalho das mulheres".

\section{Como o papel tradicional das mulheres afeta a executiva}

Telma, da Texaco, assim se posiciona:

Eu, particularmente, sempre achei as mulheres muito passivas, muito acomodadas à sua situação. Sempre briguei muito por objetivos, metas, tendências de realização profissional - mas não era maioria do pessoal que trabalhava e estudava na faculdade de informática nas boas instituições do Rio de Janeiro. Grande parte delas foi para o emprego público... acomodando-se naquele cantinho... por falta de garra, batalha. Hoje em dia isto tem mudado, as mulheres são executivas número um - em nível mundial e também no Brasil. Antes havia poucas, hoje em dia vemos as mulheres querendo se impor, caminhar, crescer...

Outra entrevistada comenta:

... acho que as mulheres têm uma desvantagem pessoal no mercado, porque elas têm uma carga maior - cuidar de filho, de casa. Uma série de coisas que ocorrem na vida da mulher e não na do homem... Há uma pesquisa de uma americana sobre mulheres que ganhavam mais de 100 mil dólares por ano: mais de 50\% não tem filhos nem é casada. Sendo que só $20 \%$ eram sós por opção - as outras não conseguiam formar família simplesmente.

Sebastiana, outra entrevistada, considera que 
...houve um amadurecimento muito grande no Brasil com a abertura política e com a ampla participação das mulheres em todos os níveis no país - seja no nível político, no técnico, profissional, nas artes... Vemos que os candidatos à presidência do país procuram mulheres para integrarem suas chapas! É o reconhecimento de que a participação das mulheres é importantíssima.

Ângela, da Wella, acredita que

...a mulher tradicionalmente tem que ser uma boa mãe, uma boa esposa, uma boa dona de casa... e acrescente a isso uma boa profissional. Tem que ter uma boa formação e estar competindo no mercado - o que implica estudar e se atualizar. Isso é complicado para quem tem todas essas atribuições...

\section{Programas de diversidade e de ações afirmativas}

Cláudia, diretora da L'Oréal, como outras entrevistadas, não cita programas ou organizações que se destacam na promoção de mulheres; ela cita o número mínimo de mulheres famosas por ocuparem altas posições: é o caso de Maria Silvia, ex-presidente da Companhia Siderúrgica Nacional e de Marluce, da Rede Globo de Comunicações. "São altíssimas executivas que ganham mais de um milhão por ano, porém podem ser contadas nos dedos". Telma, da Texaco, como outras entrevistadas, não conseguiu lembrar de nenhum caso específico de organização ou programa, a não ser a sua: "Na Texaco, o teto de vidro foi rompido com a fusão da empresa com a Xedron. A nossa número um lá é uma mulher sênior em nível mundial". Cita também outra token woman: "Na fusão da HP com a Compaq, a presidente é uma mulher. Estão começando a ser quebrados esses paradigmas". Sobre política organizacional fez questão de posicionar-se: "Sou contra a política de cotas por princípio".

A gerente da Coca-Cola entrevistada entende a cultura como a "soma das pessoas".

O que contribui ou bloqueia é o preconceito das pessoas responsáveis pela administração. Hoje em dia diversidade virou moda, de dez anos para cá processos contra a discriminação ocorrem, principalmente nos EUA, e a gente vê o reflexo nas empresas multinacionais daqui que estão ligadas à matriz. A Coca-Cola mesmo recebeu um processo acerca de discriminação contra minorias: um grupo de funcionários entrou na justiça contra a empresa, um processo enorme que gerou um acordo (envolvendo uma série de medidas e indenizações), isso em 2000. 
Andréa vê uma série de medidas possíveis envolvendo a cultura organizacional, ainda não postas em prática pela Coca-Cola: "...um programa de mentores para minorias, garantir que um percentual das vagas sejam ocupadas por minorias, garantir que candidatos das minorias participem de processos seletivos, criar cotas etc."

É também Andréa quem afirma desconhecer programas de empresas brasileiras dirigidos às mulheres:

Não conheço programas de empresas que tenham como foco a mulher. Mas há empresas atualmente enfocando deficientes físicos - a Rede Globo de Comunicações seria uma delas. $O$ Banco de Boston, sob a presidência de um americano negro, desenvolveu todo um programa com crianças carentes - não é de cotas, mas de inclusão. Eles dão toda a educação a esses carentes, incluindo formação cultural - levando à ópera, ao cinema, pois não adianta pegar um adolescente e trazer simplesmente para trabalhar aqui sem formação alguma... provavelmente ele vai fracassar. Formar o cidadão antes do trabalho é a idéia. É uma pressão da sociedade que cai sobre a empresa: os consumidores são negros, mulheres. A pressão é econômica. No Brasil, a gente está começando a discutir diversidade.

Dora, da Xerox:

Conheço as políticas das empresas americanas, que cuidam dos minorities groups (hispânicos, mulheres, negros ). A política de cotas que eles empregam é para acelerar o processo. Mas a questão da competência foi sendo substituída por uma determinação organizacional...

Sobre a política de cotas, há quase uma unanimidade de opiniões contrárias: "Sou contra isso, para mim você tem que ser admitido e promovido por competência, por qualificação, não interessa se você é homem ou mulher, negro ou branco..."(Valéria, Indústrias Gross). Essa opinião se respalda na idéia do mérito, da competência como fator único de ascensão na empresa.

\section{Exigência diferencial de desempenho de mulheres com relação aos homens}

Telma, da Texaco, opina: "A gente tinha de fazer o dobro do outro para provar que era boa executiva, nos anos 80. Depois, com a competência das muIheres mais bem assimilada, não se necessitava mais disso..."

Cecília, do Banco do Brasil: 
Se um homem tiver determinado nível de capacitação ele não precisa provar muito que é competente, mas as mulheres precisam - eu vejo isso na empresa. Se quiser galgar ou manter um determinado cargo vou ter que provar mais do que o homem que eu sou competente, vou ter que realizar mais do que o homem. Acho que a grande maioria de mulheres em nível gerencial sente isso. Tivemos uma reunião de mulheres gerentes e esse assunto foi ventilado.

Dora, gerente da Xerox:

A mulher não pode ter deslizes, para estabelecer o seu status quo tem de ser mais atuante, mais agressiva em termos de trabalho, mais pontual, tem de estar presente em todos os momentos usando sua criatividade, tem de ser forte para poder ser reconhecida...

\section{Identificação de estilos de liderança femininos e masculinos}

As percepções foram variadas em relação a essa questão: Luciana, da Editora Record, não encara o estilo das altas executivas como diferente do dos homens: “...não encontro nelas nenhuma marca feminina”. Valéria, das Indústrias Gross, também não vê diferenças entre os estilos de liderança:

O que eu vejo é que para cada cargo há que se ter determinadas características que atendam aquele perfil profissional. Uma pessoa para ser dirigente tem que ter com certeza visão holística, visão sistêmica, capacidade analítica, estratégica, ter liderança, ter marketing de relacionamento, conhecimento técnico...

Andréa, da Coca-Cola, afirma:

...já tive chefe homem e chefe mulher e não conseguiria te dizer que as mulheres são de um jeito e os homens de outro. As pessoas é que são diferentes. As mulheres com quem eu trabalhei eram extremamente assertivas e analíticas e trabalhei com homens não assertivos e não analíticos, mas baseados em sentimentos (...) No passado as mulheres eram criadas de um modo que as levava a se preocuparem mais com os sentimentos das pessoas. Na cultura corporativa das empresas não há muito espaço para esse perfil do feeling. As mulheres que vão para as corporações já são aquelas que têm um perfil mais lógico e racional, que as corporações acabam valorizando: você é contratado para tomar decisões, gerenciar, administrar. A cultura corporativa valoriza essa forma de agir e as mulheres que acabam tendo sucesso na 
corporação são que se alinham com isso. Eu não diria que a mulher tem que se transformar em homem para ter sucesso... mas acho que essas mulheres que trabalham como executivas das empresas já têm uma personalidade consoante com essas exigências. Você não muda a cultura da empresa: ou você se adapta ou acaba saindo.

No outro extremo situam-se depoimentos como o de Telma, da Texaco:

Acho que o estilo da mulher é totalmente diferente do dos homens. A mulher tem... um feeling muito mais apurado que o homem - o homem é muito mais racional. $E$, efetivamente, a melhor coisa para diferenciar um negócio não é a racionalidade totalmente pura. Para lidar com clientes, para lidar com seus liderados, não é só no chicote que você consegue... mas também não é só sendo paternalista. É uma mistura do tipo maternal, sem perder o senso de disciplina, o senso da responsabilidade... a chefe exige, dá "palmada" se necessário. Ela exercita isso 24 horas por dia. Vou dar um exemplo: os "meninos" (barbados com idade) chegam aqui com problemas particulares e vêm contar! Quando têm alguma mazela amorosa ou familiar eles não vão contar para um gerente homem... é a hora do colinho! Olha que sou descendente de alemães, cobro muito, dou duro. Mas já ouvi falar que a mulher tem a liderança emocional mais forte do que o homem.

Outra entrevistada que acredita em diferenças de estilo de liderança segundo o sexo é Silvana, da ATL:

O estilo é bem diferente. Os homens têm um estilo mais autoritário, mais centralizador - as mulheres são mais persuasivas, elas têm um estilo de liderança um pouco diferente, são intuitivas. Dificilmente você encontra mulheres em cargo de gerência que não procurem persuadir, conquistar o subordinado para a posição que ela acha certa. Há uma sensibilidade maior que sai da coisa cartesiana, racional, linear. Quando ela consegue um equilíbrio entre as duas posições a carreira deslancha. Afinal, a mulher já tem que ter um jogo de cintura para a pluralidade de papéis de mãe, esposa e profissional.

Na mesma linha posiciona-se Cecília, do Banco do Brasil:

Eu acho que tem diferenças. A mulher é mais sensível, mais direta. Essa coisa de discutir a relação não é só em casa, mas com o seu funcionário, no trabalho. A mulher percebe com mais facilidade, ela trabalha a intuição. As mulheres fazem várias coisas ao mesmo tempo - assumem vários papéis na família: é mãe, esposa e 
filha, além de estar no mercado de trabalho. Tem mais versatilidade, mais jogo de cintura. Mas, às vezes, para não perder oportunidades, ela se masculiniza.

Com essa tendência concorda Ângela, da Wella: "Essas mulheres que estão no topo são duronas, por isso é que estão lá. Têm estilo de liderança parecido com o dos homens - mais racional, pensando mais friamente...". Ao mesmo tempo em que a literatura reconhece diferenciação em termos de atributos pertencentes às mulheres, Ângela acredita que essas diferenças podem ser mero pretexto para dificultar a carreira feminina, isto é, o reconhecimento das diferenças implicaria reforço das desigualdades. Nesse contexto, as mulheres mimetizariam os homens para ganhar aceitação organizacional, abre-se espaço para o surgimento da "dama de ferro" que assimila um alto nível de dureza e rigidez comportamental, típica das instituições militares...

\section{CONSIDERAÇÕES FINAIS}

No Brasil, no ano 2000, cerca de $24 \%$ dos cargos de diretoria, no setor formal, são ocupados por mulheres, percentual maior do que o esperado, à luz dos estudos sobre o trabalho feminino que enfatizam os obstáculos encontrados pelas trabalhadoras para ter acesso a cargos de chefia. Entretanto, os dados analisados no segundo tópico do texto mostraram que esses cargos concentram-se em áreas tradicionais femininas, como a social, a cultural e a da saúde. Ou seja, mesmo nos níveis mais elevados da carreira, as executivas brasileiras marcam presença sobretudo em tradicionais guetos femininos. Elas são mais jovens do que os diretores, estão há menos tempo do que eles na diretoria e predominam em empresas de maior porte. Têm nível superior de escolaridade, porém, apesar do alto cargo ocupado, recebem rendimentos inferiores aos de seus colegas diretores.

As executivas entrevistadas no item terceiro do texto alegam que esse diferencial ocorre em virtude de terem chegado mais tarde ao mercado de trabalho e ao fato de que as melhores posições ainda são ocupadas pelos homens. Todas foram unânimes em afirmar que não há diferenças salariais para os mesmos cargos. "O que existe são posições melhores ocupadas pelos homens, que estão há mais tempo no mercado, por isso ganham mais - por estarem mais bem colocados", como dizem algumas.

Apesar do diferencial de ganhos encontrado, a maioria acredita que não existem preconceitos contra as mulheres nas empresas, seja no momento da seleção 
ou da promoção, pois tanto uma como outra se baseia principalmente na "meritocracia", ou seja, em critérios de competência e dedicação ao trabalho. Algumas entrevistadas, contudo, deram depoimentos significativos sobre a cultura machista que impera nas corporações, embora esta tenha-se transformado desde os anos 80, à medida que cada vez mais mulheres ingressam nas empresas e ascendem aos postos mais elevados. Elas acreditam que a discriminação pode existir de forma escamoteada, mais invisível e, principalmente, em razão da gravidez, seja em decorrência dos quatro meses de licença-maternidade, seja em virtude das dificuldades previstas com os filhos pequenos, como menor disponibilidade para viagens. Acreditam que não existe discriminação no sentido estrito, embora, de fato, as promoções ocorram com mais facilidade para aquelas que têm mais chances de se locomover. Admitem que estar disponível 24 horas por dia para a empresa implica menor convívio com os filhos. Estar em eventos, reciclar-se, viajar, é difícil para quem tem filhos pequenos. É por isso que fazem escolhas objetivas de carreira: "uma gerência média permite conciliar melhor os papéis pessoais e profissionais do que uma gerência geral, que requer muitas viagens".

As entrevistadas divergem em relação aos preconceitos existentes na contratação e/ou na promoção de mulheres. Segundo elas, há lideres que preferem trabalhar com mulheres, outros com homens. "Depende muito da atividade que ela vai desenvolver". Algumas lembram que a presença de um "mentor", isto é, de um guia ou mestre, pode ser útil, outras, como a gerente do Banco do Brasil, lembram que a contratação e a promoção no setor público se dão mediante concurso, o que evita a possibilidade de discriminação.

A ascensão é vista por algumas entrevistadas como conseqüência "natural" da conquista de espaços, consideração otimista que aparece, entre outros, em depoimentos que rejeitam propostas de políticas protecionistas do tipo "discriminação positiva", como a determinação de um número mínimo de vagas a serem preenchidas por mulheres. Sobre o tema da política de quotas, há quase uma unanimidade de opiniões contrárias: "Sou contra isso, para mim você tem que ser admitido e promovido por competência, por qualificação, não interessa se você é homem ou mulher, negro ou branco". Ao tema das cotas contrapõe-se, nos depoimentos obtidos, o da meritocracia. As entrevistadas foram unânimes em afirmar que escolher um profissional que vai exercer uma função de gestor implica competência em cima de resultados, independentemente de uma eventual condição minoritária: saber fazer, saber por que faz e saber liderar uma equipe (...). 
A educação, como um pré-requisito, foi mencionada quase unanimemente pelas entrevistadas; segundo elas, cada vez se torna mais importante a titulação, ter uma excelente formação acadêmica etc.

Outras entrevistadas, no entanto, embora concordem que a formação é fundamental, acreditam que a cultura corporativa ainda conta muito, pois a executiva

...tem de ser durona, tem que se impor, se colocar, mostrar que é melhor. Ela sempre tem que dar algo a mais que o homem, mostrar que sua vida pessoal não está influenciando seu dia-a-dia de trabalho, mostrar que não é frágil. Mandar, se fazer respeitar, não chorar - são tradições masculinas, que fazem parte da cultura corporativa, que ainda impera nas corporações, porque nelas os homens detêm as melhores posições. Ao mesmo tempo, essa cultura favorece os homens e os ajuda a se manterem nessas posições.

Nas falas das entrevistadas, entretanto, há muitas contradições em relação às características pessoais das executivas, dentro da cultura corporativa dominante. Umas acreditam que o estilo da mulher é totalmente diferente do dos homens, pois a mulher tem um feeling muito mais apurado que o homem - "o homem é muito mais racional". Outras argumentam que não, com base em sua experiência pessoal:

...já tive chefe homem e chefe mulher e não conseguiria te dizer que as mulheres são de um jeito e os homens de outro. As pessoas é que são diferentes. As mulheres com quem eu trabalhei eram extremamente assertivas e analíticas e trabalhei com homens não assertivos e não analíticos, mas baseados em sentimentos.

Outras acham ainda que na cultura corporativa das empresas não há muito espaço para esse perfil do feeling. As mulheres que vão para as corporações já são aquelas que têm um perfil mais lógico e racional, que as corporações acabam valorizando: "...você é contratado para tomar decisões, gerenciar, administrar". A cultura corporativa valoriza essa forma de agir e as mulheres que acabam tendo sucesso na corporação são aquelas que se alinham com isso.

Eu não diria que a mulher tem que se transformar em homem para ter sucesso... mas acho que essas mulheres que trabalham como executivas das empresas já têm uma personalidade consoante com essas exigências. Você não muda a cultura da empresa: ou você se adapta ou acaba saindo. 
De modo geral, porém, as entrevistadas concordam que a cultura corporativa influencia bastante e que as empresas mais tradicionais ou machistas não vão dar às mulheres cargos-chave. Além disso, têm consciência de ter, como qualquer trabalhadora, uma desvantagem pessoal no mercado, uma carga maior: cuidar dos filhos, da família, da casa. E, enquanto esta desvantagem não for superada, dificilmente poderão dedicar-se integralmente à carreira escolhida, galgando seus degraus mais elevados. Mas, como acreditam também que contra a competência não há argumentos, acham que é possível conseguir um equilíbrio entre o lado familiar e o profissional. Ou seja, a julgar pelas opiniões das executivas entrevistadas, fazer valer o predomínio da competência sobre a cultura corporativa machista requer não só a ocupação de mais espaços nesse nicho ocupacional de elite, mas também a obtenção de um equilíbrio entre o lado familiar e o profissional.

\section{REFERÊNCIAS BIBLIOGRÁFICAS}

BRASIL. Ministério do Trabalho. Rais. relação anual de informações sociais. Brasília, 2000. CD-ROM.

BRUSCHINI, C. Gênero e trabalho no Brasil: novas conquistas ou persistência da discriminação? (Brasil, 1985-1995). In: ROCHA, M. I. B. da (org.) Trabalho e gênero: mudanças, permanências e desafios. São Paulo: Editora 34, 2000. p. 13-58.

BRUSCHINI, C.; LOMBARDI, M. R. A Bipolaridade do trabalho feminino no Brasil contemporâneo. Cadernos de Pesquisa, São Paulo: FCC, n. I l 0, p.67- 104, jul.2000.

Médicas, arquitetas, advogadas e engenheiras: mulheres em carreiras de prestígio. Estudos Feministas, v.7, n. I/2, p.9-24, 1999.

FUNDAÇÃO CARLOS CHAGAS. Banco de dados sobre o trabalho da mulher. Disponível em: http: www.fcc.org.br.

ORGANIZAZIÓN INTERNACIONAL DEL TRABAJO. Yearbook of labour statistics, 1996. Washington: PRB, 1997.

Recebido em: dezembro 2003

Aprovado para publicação em: janeiro 2004 